\title{
ИЗ ОПЫТА ИСПОЛЬЗОВАНИЯ ИГРОВЫХ ЗАДАНИЙ И ТЕСТОВ ПРИ ОБУЧЕНИИ КРАЕВЕДЕНИЮ
}

\section{FROM THE EXPERIENCE OF USING GAME TASKS AND TESTS IN TEACHING LOCAL HISTORY}

\section{T. Lebedeva}

Summary: In the article the author shares the experience of applying various types of educational tasks in the study of geography and local history. Unlike most researchers who use game tests only for final check, the author offers to use such tasks during classes with young local historians in the off-season, when outdoor classes (expeditions, hikes) are impossible due to weather conditions.

Keywords: methods of teaching local history, game tests, quizzes, educational crosswords, local history tales.
$\mathrm{H}$ ет необходимости доказывать важность изучения краеведения в школе и как первой, начальной ступени в процессе изучения окружающего мира, и как главного воспитательного инструмента, формирующего у школьников сознательный, а не декларативный патриотизм, глубокое понимание уникальности родного края, его неповторимой привлекательности.

Однако в современных школьных программах эта дисциплина появляется лишь эпизодически, в годы, предшествующие юбилеям (в Москве, например, в преддверии 1997 г.). В этом смысле Ивановская область, где работает автор данной статьи - не исключение. Празднование 100-летия Иваново-Вознесенской губернии (ныне - Ивановской области) вызвало всплеск активности в местном краеведческом сообществе и в школьном краеведении - в частности.

Тем не менее, тесные рамки и без того перегруженной школьной программы, поневоле заставили учителей-энтузиастов, стремящихся привить своим питомцам любовь и родному краю, прибегать к внеурочным формам работы и, в частности, и организации краеведческих кружков, школьных музеев, а также краеведческих школьных походов и экспедиций.

Всем, кто занимался кружковой работой такого рода, хорошо известны и плюсы и минусы этой формы обучения. Создание небольшого (редко более 15 человек) круга заинтересованных и любознательных ребят, а также смена пассивного восприятия материала активным
Лебедева Татьяна Владимировна

преподаватель, ОГБПОУ «Ивановский железнодорожный колледж» lebtv2013lebedeva@yandex.ru

Аннотация: В статье автор делится опытом применения различных типов учебных заданий при изучении географии и краеведения. В отличие от большинства исследователей, использующих игровые тесты лишь для итогового контроля, автор предлагает пользоваться такими заданиями в ходе занятий с юными краеведами во время межсезония, когда натурные занятия (экспедиции, походы) невозможны из-за погодных условий.

Ключевые слова: методика обучения краеведению, игровые тесты, викторины, учебные кроссворды, краеведческие сказки.

процессом постижения географии, биологии, истории и культуры родного края, естественно возникающие при этом межпредметные связи - несомненные преимущества кружкового метода. Добавим к этому, что краеведческая работа немыслима без полевых исследований, а они являются не только мощным фактором, активизирующим процесс познания, но и средством сплочения коллектива, развития личных качеств юных краеведов.

Однако при всех своих преимуществах полевые исследования в условиях средней полосы России возможны лишь четыре месяца в году: в апреле-мае и сентябре-октябре (не считая летних каникул). В период же межсезонья организация натурных занятий часто затруднена, поскольку дожди, туманы, морозы и метели резко сужают возможности для проведения походов и экспедиций.

И здесь на помощь приходят игровые задания и тесты, позволяющие сделать интересными и необычными даже кабинетные кружковые занятия.

Основные виды таких заданий и методика их применения детально разобраны на примере географических тестов $(1,5,14$ - 16). За годы работы в школьном краеведении (20 лет - в сельской школе и 5 лет в городском колледже) у автора также накопился некоторый опыт использования нестандартных игровых технологий, позволяющих сохранить интерес и поддерживать умственную активность обучающихся во время занятий в школьных стенах. Хотелось бы поделиться этим опытом 
и проанализировать сравнительную эффективность и привлекательность различных видов кабинетных заданий для юных краеведов.

Два года назад автор подготовил и издал небольшой сборник таких заданий /10/, который оказался весьма востребован в школах Ивановской области, так что вскоре потребовалось его переиздание.

В сборнике представлены 15 видов заданий, большинство из которых известны давно и охватывают широкий круг предметов [2-5, 8-9, 14-17], причём среди них явно преобладают дисциплины естественнонаучного профиля. Что же касается краеведческих заданий, то им посвящены лишь единичные работы [6-7, 10].

Кроме чисто игровых заданий в сборник были включены и такие, которые наиболее часто используются при итоговых аттестациях (ОГЭ, ЕГЭ) и ВПР. Среди них были такие как «Найдите соответствия», «Разбейте слова на две группы», «Выберите нужное» и «Удалите лишнее». Следует отметить, что, хотя кружковцы успешно справились с заданиями этих типов, они вызывали у ребят наименьший интерес. Гораздо охотнее и азартнее школьники выполняли задания, в которых не нужно было выбирать из готовых ответов, такие, как кроссворды, чайнворды, задания типа «На одну букву», краеведческие диктанты, «Мини-викторины», «Краеведческие сказки».

Последний, из перечисленных типов заданий, был впервые предложен автором с целью заинтересовать младших школьников. Однако неожиданно оказалось, что эти сказки вызывают интерес и у их старших товарищей.

Учитывая это, автор дополнил шестнадцать сказок сборника ещё тридцатью новыми и издал их отдельной книгой под названием «Сказки серого камня» [11], который так же быстро разошёлся и сейчас входит вторым изданием. В 2021 году автором был издан сборник краеведческих сказок "Сказки красного камня», который продолжил знакомить юных краеведов с историей, природой и культурным наследием Ивановского края [12].

Кроме занятий с игровыми тестами, хорошей формой работы в межсезонье является изучение топонимии родного края (в первую очередь своего района, и затем и области в целом).

Успешному внедрению топонимики в практику занятий краеведческих кружков способствовал выход в свет первого в истории полного топонимического словаря Ивановской области [13], подготовленного автором и изданного в виде восьми выпусках в 2017-2018 гг.

Большую часть ивановских топонимов составляют имена селений, среди которых более 90\% происходят от названий природных объектов (Горки, Родники, Заречье, Заболотье, Подберезье, Лужок и др.), а также от имён их основателей с первопоселенцев. Среди последних преобладают не православные имена, а имена-прозвища (Медведево, Зайцево, Хромово, Косово, Рыжово, Хитрово, Буяново, Хмелёво, Обухово, Чурбаново и т.п.). Предлагая школьникам найти на карте или в словаре названия природного характера, учитель акцентирует внимание кружковцев на географических особенностях местности (задание ограничивается по времени и побеждает нашедший наибольшее число нужных топонимов). Названия, связанные с именами-прозвищами, помогают узнать черты быта и хозяйства старой деревни, профессии жителей, их привычки.

Выполняя задания на занятиях кружка, юные краеведы используют не только конспекты занятий и краеведческий атлас области, но и приложения к сборнику тестов, содержащие краткую характеристику животного и растительного мира Ивановского края, перечень рек, озёр и городов области, таблицу, содержащую имена исторических деятелей и деятелей литературы, искусства и науки, живших и творивших в нашем крае.

Однако в каждом кружке находятся школьники, которые, не пытаясь что-то вспомнить или сообразить, сразу обращались к приложениям и бездумно, механически пытаются подобрать ответы к упражнениям. Понятно, что такая манера не добавляет знаний ученику, даже если он успешно решит кроссворд либо, иное упражнение. Чтобы активизировать процесс поиска и сделать его осознанным и пополняющим эрудицию, автор нередко раздавал своим питомцам не книги, а ксерокопии заданий. Лишённые возможности использовать приложения, кружковцы поневоле обращались к словарям, содержащим краткую информацию по изучаемым направлениям. Серия таких популярных словарей для юных краеведов была также подготовлена автором и вышла из печати в 2019-2020 гг. В неё вошли биологический словарь «Живая природа», архитектурный словарь «Из дерева и камня», текстильный словарь «В мире тканей», исторический словарь «Прошлое в лицах», топонимический словарь «Имя на карте».

Эти словари содержат краткие характеристики рассматриваемых объектов, и, работая с ними, школьники мало-помалу расширяют свой кругозор и приучаются работать со справочной литературой [14-15].

Завершая свою статью, ещё раз подчеркнём её главную мысль. Многолетний опыт автора, полученный как в рамках школьных занятий, так и в процессе внеурочной работы, позволяет считать занятия с использованием игровых заданий эффективным средством краеведче- 
ской кружковой работы в период межсезонья.

В заключение следует отметить, что между сельскими и городскими школьниками наблюдается определённые различия, чётко выявляющиеся при работе с краеведческими заданиями. Сельские ребята, лучше городских справляются с упражнениями природно-краеведческо- го характера, а городские обладают более значительным историко-культурным багажом. Разница проявляется и в знании исторических деятелей. Сельские школьники лучше знают писателей и поэтов, а городские - полководцев и композиторов. Все эти различия резче проявляются у начинающих кружковцев и постепенно исчезают у юных краеведов со стажем.

\section{ЛИТЕРАТУРА}

1. Баринова И.И. Занимательная география. Любопытные факты, кроссворды. М.: «Школа-Пресс», 1992. - 96 с .

2. Башкатова К.Р. Лесные головоломки. М.: Московский учебник, 1994. - 128 с.

3. Богданова Г.А., Русский язык. Рабочая тетрадь. Вып. 1. М.: Генжер, 2016. -64 с.

4. Босова Л.М., Босова А.Ю. Информатика. Рабочая тетрадь. М.: БИНОМ, 2001.- 104 с.

5. Вагнер Б.Б. География мира и России. Задачи, тесты, познавательные игры. М.: Наука, 1998. -168с

6. Вагнер Б.Б. Игровые тесты на уроках московедения. М.: Московский Лицей, 2001, - 96 с.

7. Вагнер Б.Б. Краеведение Московского региона в тестах и игровых заданиях. М.: Изд. МГПу, 2011. - 108 с.

8. Голубева Е.Б. Естествознание. Нескучный учебник. СПБ.: Тригон, 1997.- 388 с.

9. Заянчковский 0.С. Занимательная зоология. Саратов: 1971. - 244 с .

10. Лебедева Т.В. Краеведение Ивановской области в тестовых и игровых заданиях. Иваново: 2019. - 96 с.

11. Лебедева Т.В. Сказки серого камня. Сказочные истории для юных Ивановских краеведов. Иваново, 2020 - 164 с.

12. Лебедева Т.В. Сказки красного камня. Сказочные истории для юных Ивановских краеведов. Иваново, 2021 - 120 с.

13. Лебедева Т.В. Имена земли Ивановской. Вып. 1-8, Иваново, 2017-2018.

14. Лебедева Т.В. В мире тканей. Текстильный словарь для юных краеведов// - М.; Филинъ, 2019. -50 c.

15. Лебедева Т.В. Живая природа. Биологический словарь для юных краеведов. // - М.; Филинъ, 2021. - 120 с.

(с Лебедева Татьяна Владимировна (lebtv2013lebedeva@yandex.ru).

Журнал «Современная наука: актуальные проблемы теории и практики»

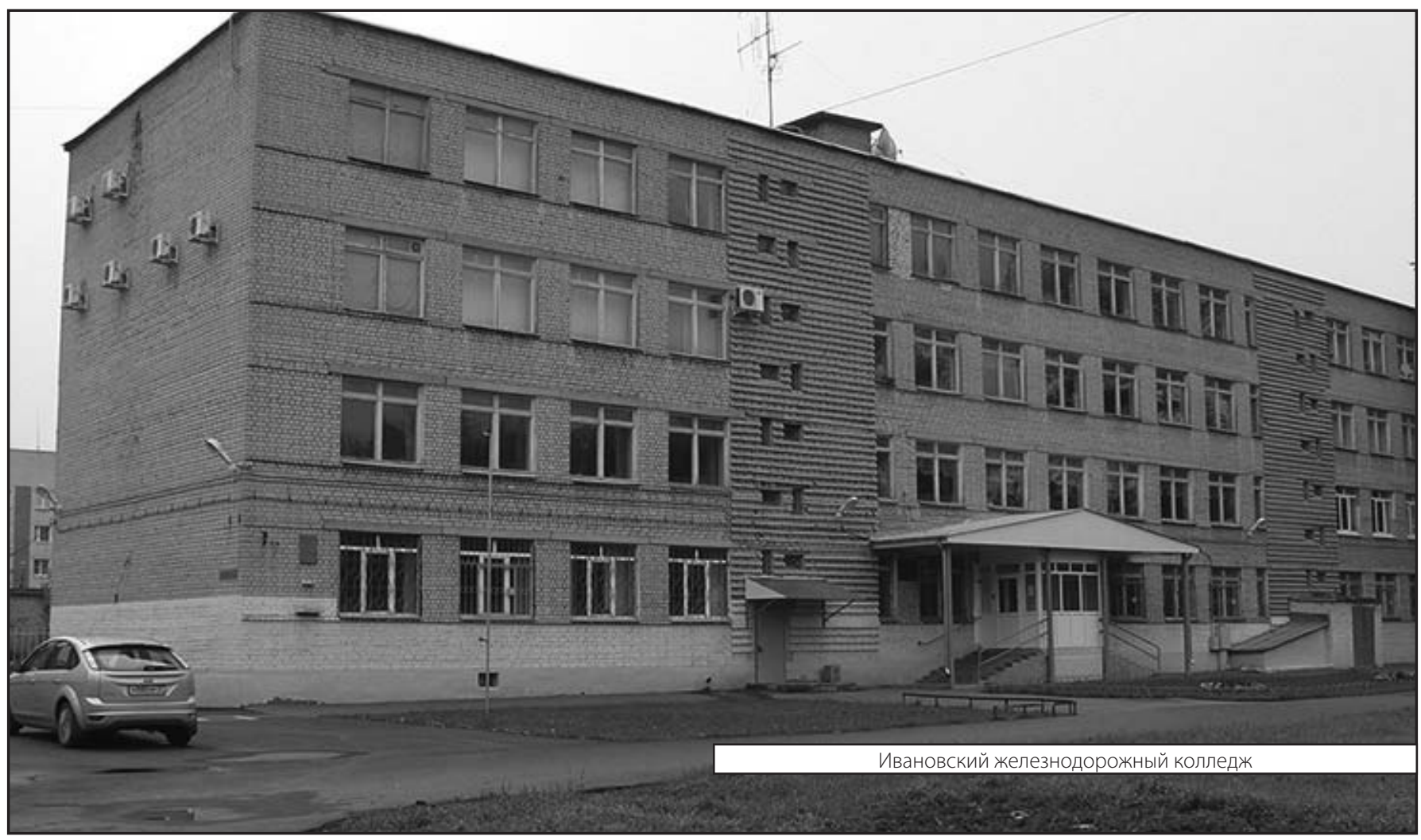

